\title{
BRIEVEN UIT SURINAME.
}

\author{
DOOR
}

R. D. SIMONS.

De rede, waarmede Baron van Heemstra op 23 Mei j.l. het bestuur over. onze kolonie aanvaardde is zeker aan de lezers van De West-Indische Gids bekend, misschien zelfs in het tijdschrift opgenomen ${ }^{\mathbf{1}}$ ). Het zij mij veroorloofd de volgende perioden daaruit hier aan te halen:

„Niet minder dan aan het voorafgaande zal onze bijzondere aandacht gewijd blijven aan de ontwikkeling van de rijke hulpbronnen van dit schoone tropenland.

Hoewel in niet geringe mate eerbied en bewondering gevoelend voor hetgeen meerdere mijner ambtsvoorgangers ten deze hebben verricht, waag ik het op te merken, dat bij dit alles niet steeds een systematische grondgedachte heeft voorgezeten, weshalve mij thans het oogenblik gekomen lijkt, waarop voor nu en langeren tijd, de vaste lijnen zijn aan te geven, waarlangs wij ons het voortbewegen van de economishe evolutie dezer kolonie zullen kunnen denken.

Indien het ons mag gelukken, in wel overwogen opzet, een deugdelijk werkplan samen te stellen, hetwelk voor langere periode alles omvat wat voor den opbloei van den landbouw, voor de vorming van de industrie, als ook voor de onmisbare exploratie van binnenland en bodem noodzakelijk schijnt, dan zal zoodanig werkplan, ik ben ervan verzekerd, de sanctie van het Parlement in ons Moederland verwerven en zullen van Staatswege de gelden, hoe aanzienlijk ook, voor de geleidelijke uitvoering van dit plan worden beschikbaar gesteld."

Ik behoef niet te verzekeren dat wij spoedig hopen te vernemen in welke richting de nieuwe landvoogd 't zoeken zal, konkrete verlangens en wèl omschreven plannen te hooren. Ik kan 't mij voorstellen, dat de heer van Heemstra in de nieuwe omgeving

1) Zie de Juli-aflevering, blz. 173.

De Redactie. 
nog wat speurt, nog spoor zoekt, maar laten we straks horen, dat hij „lucht heeft” en toeloopt: „Dààr!” „Dat wil ik!”

Ach, dat de plannen niet te lang uitblijven, want het „oriënteren" is onze dood! Een nieuwe minister ,oriënteert "zich en net als hij misschien zou menen klaar te zijn, maakt een verkiezing of 'n krisis of wat dan ook 'n eind aan z'n eksellent leven. En hebben we al een georiënteerde ,raadsman der Kroon”, dan is 't net $\mathrm{h}$ i e $\mathrm{r}$ verwisseling van landvoogd en de oriëntering moet weer te Paramaribo plaats hebben. Ad infinitum! Om en om!

Een der eerste konferenties van Baron van Heemstra was met de daartoe uitgenodigde redakteuren van de drie hier verschijnende grotere bladen, de twee maal 's weeks verschijnende.

Grotere bladen" en twee maal 's weeks gedrukt! Ja, daar ziet de Hollandse lezer, die deze regels onder de ogen krijgt, raar van op, de Hollandse lezer, die dageliks z'n morgen- en avondblad en misschien nog een middag-editie in z'n brievenbus hoort ploffen.

Maar we zijn nu eenmaal hier in een dun bevolkt landje en we doen 't allemaal op bescheiden schaal. Het is misschien daarom dat hier de pers wel eens wat al te zeer en bagatelle wordt behandeld. Maar men vergeet, dat hier net zo goed als elders „de krant" de dubbele rol vervult van opinie-vormer en opinie-vertolker en dat men verkeerd doet de invloed al te veel te onderschatten.... of te doen, alsof men die onderschat.

't Is wel eens gebeurd en wel meer dan eens gebeurd, dat een of ander ambtenaar het verwonderdste gezicht zette, als hij hoorde, dat er iets (gewoonlik dan 'n minder vleiende beoordeling) over hem in de krant te lezen was, omdat hij, „dat blaadje nooit inkeek", terwijl Frau Beambter op dezelfde dag kond deed, dat ze weer haar wijzer helft hadden „,zwart gemaakt”, maar dat hij zich er niets van aantrok en dat zij samen, de vorige avond om dat geschrijf hadden gelachen. Zo zijn er!

Om op de konferentie terug te komen; goeverneur van Heemstra heeft getoond te begrijpen, dat de pers, groot of klein, z'n invloed heeft en hij heeft zich tot de pers gewend om die te hulp te roepen bij de vervulling van de op zich genomen taak. Bij wederzijds vertrouwen kan veel worden gedaan, vooral veel worden voorkomen, want ook dit plekje wereld wordt vaak door misverstand beheerst.

Aan de bladen werd toegezegd, dat op de reizen van de goeverneur telkens een vertegenwoordiger zou worden uitgenodigd 
en dadelik werd een klein loterijtje georganiseerd om de volgorde te bepalen, waarin aan de tochten zal worden deelgenomen.

De goeverneur meende ook, dat getracht moest worden kontakt te verkrijgen met de grote "pers-zusters” in Holland en dat in de Moederlandse bladen geregeld berichten uit Suriname moesten worden gegeven. ${ }^{1}$ )

Kon 't maar! Dit zou meewerken om het soms verbijsterende gebrek aan kennis betreffende de kolonie te doen verminderen. Ik weet, dat vaak pogingen mislukt zijn om van een Nederlands blad de toezegging te krijgen, dat het geregeld berichten uit Suriname zou opnemen, omdat, zoals onomwonden werd meegedeeld, daarvoor bij de lezers niet genoeg belangstelling zou te vinden zijn. Ach Suriname ook, dat „eiland” niet waar - let maar eens op hoeveel personen (vooral bij de équipage van boten is mij dit opgevallen) spreken van „op” Suriname! — ach Suriname, waar de tijgers door de straten sluipen en de slangen als levende draperiën bengelen aan de zoldering! Dergelijke verhalen, voor Oost-Indië al naar het rijk der fabelen verwezen, zijn voor dit goeie, veilige land nog in volle vigeur.

Ik geloof ook wel, dat er inderdaad weinig belangstelling is voor dit typies Nederlands gewest, dat, nu en décadence, eenmaal toch de middelen gaf, waarmee menige Amsterdamse patriciërswoning werd ontworpen en voltooid.

$\mathrm{Nu}$ de belangstelling ontbreekt, is 't aan $\mathrm{U}$, grote persorganen, om die weer op te wekken: Nederland is groter, dan het deel, dat door de Noordzee wordt bespoeld, maar omvat meer ook dan die kostbare smaragden om de evenaar ; daar zijn nog parelen in de Westelike zeeën, al dreigt daarvan helaas de glans te worden verdoofd.

Baron van Heemstra heeft ook een bezoek gebracht aan alle landskantoren en een zitting van het Hof van Justitie bijgewoond. Ik begrijp ' $t$, dat dit eerste bezoek is aangekondigd en dit nut heeft 't althans gehad, dat ik hier en daar lokalen, hokjes en vloeren een schoonmaakbeurt heb zien krijgen, die ze allang rechtmatig hadden kunnen eisen. Zulke bezoeken zijn dus heilzaam, maar ik zou de nieuwe bewindsman bescheiden in overweging willen geven, die meer à la Haroun-al-Raschid oftewel op z'n onverwachtst en met stille trom af te leggen. Dan ziet men alles, zoals het gewoonlik w è 1 is!

\footnotetext{
1) De groote bladen nemen geregeld berichten uit de Surinaamsche couranten over. „Het Koloniaal Weekblad” doet dat.
} 
Met de grote landbouw botert het nog niet. Het schijnt, dat door de koffie-ondernemingen wel steun zal worden verkregen onder de nodige waarborgen en dan van 50 cent per kilo. Belanghebbenden achten dit niet voldoende: „de kostprijs is meer”. Hetgeen weer door anderen betwijfeld wordt, met dien verstande, dat als men de gehele aanleg meerekent, men tot een hoger bedrag komt, maar dat men bij eenmaal bestaande kultivaties voor minder dan ,een banknoot”, alias een halve gulden, z'n produkt voor gebruik gereed kan afleveren. Ik acht mij niet bevoegd in deze uitspraak te doen - maar hoe 't zij, voor de koffie komt toch hulp, terwijl die voor de kakao, het sneller-bedervend produkt, helaas niet zal worden verleend.

„Eigenaar van een plantage in de West" - wat klonk dat vroeger Croesus-achtig; nu is 't identiek met: slachtoffer van veel hoofdbrekens en misère. Ja, $m i$ s e $r i$ possidentes, ongelukkig de bezitters; o schim van Horatius!

Van de staking der Bosnegers aan de Marowijne zullen vele lezers, die ook Oost en West onder de ogen krijgen, al hebben gehoord. De heren doen aan de beschaving mee! De motieven voor dit besluit, te Paramaribo gegeven, zijn vele en velerlei; in Frans Guyana, „aan de Franse kant”, zoals men hier zegt, zou de granman der Boni-negers al in drie jaar de hem toekomende duizend franken niet hebben getoucheerd (wat inderdaad 'n onaangename misrekening moet zijn); de heren van ons gebied zouden te Albina niet de hulp hebben ondervonden, waarop zij recht hadden; zij zouden door kooplieden met een al te lage berekening van koersen zijn geknepen, enz. enz.

De ondervoorzitter van de Raad van Bestuur en de Goevernements-sekretaris, Mr. Rietberg en Mr. Eekhout, werden daarom in kommissie naar Albina gezonden zoals aan de pers werd meegedeeld ,tot het instellen van een grondig administratief onderzoek naar de diepere oorzaken van de laatste staking der Bosnegers aan de Marowijne en al wat daarmee in verband staat".

De heren hebben drie dagen te Albina vertoefd en daar verschillende personen gehoord - het resultaat van het onderzoek is nog niet bekend. Amakti, de goeverneur van onze Djoeka's, is naar Paramaribo ontboden, maar arriveerde nog niet, was ook tijdens het verblijf van de Kommissie nog niet te Albina, zodat de diepere roerselen van 's mans gemoed en die van zijn onderdanen nog niet konden worden gepeild. 
Ook op sportgebied bracht deze maand iets memorabels. Paramaribo heeft een aantal flinke zwemmers. Een zweminrichting zijn we nog niet rijk en plannen, die daarvoor ontworpen waren, bleven in embryonale toestand door het oordeel van medici, dat de rivier - en daarin zou de inrichting moeten komen - te veel ongerechtigheden bevat dan dat die tot menselik aquarium zou kunnen dienen. Maar er zijn een aantal personen, die terwille van het zwemgenot de gevaren trotseren en daaruit zijn goede zwemmers gegroeid.

Op 12 Junie nu werd een lange-afstandstocht ondernomen: van Station Domburg naar Paramaribo. De baan, 17 KM. lang, werd door 9 van de 22 deelnemers afgelegd in ongeveer $3^{1 / 2}$ uur. De stroom werkte krachtig mee en er zouden zeker meer bereikers van het eindpunt zijn geweest, als de temperatuur van het water op die dag aan enkelen geen kramp had veroorzaakt. Onder 'n flinke slagregen moest het trajekt worden door-,,poeld" en bij zoveel hemelwater kan 't zelfs in een tropiese rivier goed fris zijn. De heren zijn nog een huldiging mis-gezwommen. Het Sportkomité stond hen op te wachten bij de marinetrap wat eerst als eindpunt was genomen, maar men ging een kwartier daarvóór aan wal, niets van de voorgenomen ontvangst vermoedende. Bij zoveel water (rivier- en regen-) misschien niet te verwonderen, dat de hulde daarin te vallen kwam.

Enfin, we kennen 't, van „uitslag” en „doel”.

Voor 't laatst bewaarde ik het voornaamste nieuws, nl. de plotselinge aanvraag van de sub-agent voor de immigratie, de heer P. Westra, om van zijn funktie te worden ontheven.

De afgetreden Agent-Generaal is nauweliks in het Moederland aangekomen of reeds heeft $z$ 'n vervanger besloten heen te gaan, passage aanvragende voor de eerste boot, die volgt op die, waarmee de heer van Drimmelen heenging.

De heer Westra heeft voor onze kolonie iets gehad van 'n meteoor.

Op 3 Januarie 1918 ontvingen de Kol. Staten plotseling een brief van goeverneur Staal, waarin werd meegedeeld, dat de heer P. Westra, kontroleur B. B. op Java en Madoera, verzocht had tijdelijk in Suriname te worden te-werk gesteld. Let wel: verzocht had!

De heer Staal was met de sollicitatie buitengewoon ingenomen en wilde "alvorens het nodige te verrichten" het gevoelen der Staten vernemen over de tijdelike aanstelling van een sub-agent. 
Het merendeel van het Kollege voelde om allerlei toen aangevoerde redenen weinig voor de zaak. De gehele geschiedenis behoeft nu niet te worden herhaald - 't eind was, dat goeverneur Staal berichtte, dat de heer Westra toch komen zou.

In een schrijven van goeverneur Staal van 4 Februarie valt o.m. te lezen: „Wel weet hij (d.i. de goeverneur) dat de heer Westra genegen is zich voor vijf jaar te verbinden en wanneer daartoe gelegenehid ontstaat, tijdelijk het ambt van Agent-Generaal te bekleeden."

De heer Westra kwam hier aan in Augustus 1918 - zijn benoeming dateert van Mei 1918 - en zie, in Junie 1921, na drie jaar dus, zodra de gelegenheid zich voordoet om als Agent Generaal op te treden, pakt hij zijn koffers.

? ? ? Ik zet er maar drie, maar er zijn heel wat meer vraagtekens. Naar het schijnt is de betrekking de heer Westra niet meegevallen. Hij schijnt zich meer bevoegdheden of de mogelijkheid tot onbeperkter optreden daarbij te hebben voorgesteld. En even plotseling als zijn komst, wordt zijn vertrek aangekondigd.

Als wij de hooggestemde verwachtingen, die bij zijn in-diensttreding door het Bestuur zijn gekoesterd, nog eens overlezen, dan moet worden erkend, dat deze proefneming of hoe men 't noemen wil, 'n mislukking is geweest.

De heer Westra zou bij het afscheidnemen van zijn personeel zich zeer denigrerend over het ambt hebben uitgelaten. Wat niet verstandig is - in de eerste plaats niet tegenover zich zelf: immers ieder ambt is, wat de funktionaris er van maakt.

Ik sprak van 'n proefneming en 'n mislukking - ze hebben de kolonie, d.i. het Moederland, 'n slordige duit gekost.

De heer Westra is in de oorlogsjaren over Amerika naar hier gereisd, heeft daar een vrij lang verblijf moeten houden, enz. Men moet toegeven, dat aan deze omstandigheden, toen tot de uitzending eenmaal besloten was, weinig te veranderen viel.

Maar nu! De heer Westra krijgt ontheffing binnen de termijn. waarvoor hij zich verbond en wat zien wij verder gebeuren?

De heer Westra valt onder de ambtenaren die krachtens het K.B. van 28 Junie 1917 (Stbl. no. 480) recht hebben op ten hoogste zes maanden wachtgeld bedragende $50 \%$ van het laatste inkomen. En nu wordt de heer Westra, nadat al bekend was, dat hij zou heengaan, ongeveer drie of vier dagen voor zijn resolutie van ontheffing, benoemd tot waarnemend Agent-Generaal. Deze bevordering, in plaats van de heer Westra nog enige weken als sub-agent het Departement te laten besturen, brengt mee, dat 
zijn salaris wordt gebracht van $f 6000$ op $f 8000$, een salarisverhoging, waarvan hij niet direkt zal kunnen profiteren, maar die zijn wachtgeld brengt van $f 3000$ op $f 4000$.

Overbodig zou men zeggen. Maar ons goevernement laat het daar niet bij. Aan de heer Westra wordt nog bovendien toegestaan twee maanden vrijstelling van dienst, die op de dag van zijn vertrek zullen beginnen te lopen. Een nergens voorgeschreven en als de ontheffings-resolutie uitdrukkelik vermeldt, ook niet vooraf bedongen voorwaarde. Maar dit cadeautje wordt (als die resolutie verder meedeelt) dan aangeboden voor de wijze, waarop de heer Westra zijn ambt heeft waargenomen en om zijn OostIndiese diensttijd zonder onderbreking aan die in Suriname te doen aansluiten, indien hij, in 't Moederland aangekomen, dadelik ,overgaat”.

Ik wil mij in deze epistelen zoveel mogelik van persoons-kritiek onthouden, maar laat ik 't zeer voorzichtig uitdrukken en zeggen dat de meningen over het beleid van de heer Westra zeer verdeeld zijn. In ieder geval zijn geen verdiensten naar buiten gebleken en hier blijkt alles nog al gauw naar buiten - die een dergelijk faveurtje opdringen, vooral niet als men alle omstandigheden in aanmerking neemt: de komst op eigen verzoek uit een (overigens op zich zelf zeer waardeerbaar) streven naar verrijking van kennis; de aftreding plotseling, juist toen de heer Westra kon tonen, wat hij vermocht; de toestemming om het dienstverband van 5 jaar zonder uitpsraak van de geneeskundige kommissie na 3 jaar te doen eindigen en in de vierde plaats, die spoed-promotie hier boven vermeld. Was het nu werkelik zo nodig, dat bij dit alles nog twee maanden salaris, d.i. 'n dikke $f 1300$ plus duurtebijslag werd present gegeven? Een dergelijke vrijgevigheid mag m.i. niet plaats hebben, als die betaald moet worden door anderen. Het subsidie-cijfer stijgt, de kolonie in groeiende misère en dan is 'n hele dikke duizend gulden een kleintje - en niet eens'n kleintje waarop wèl mag worden gepast. Wat ik alleen maar zeggen wilde!

Als vervanger van de heer Westra is tijdelik aangewezen de heer S. H. de Granada, de oudste distrikts-kommissaris. 